5. Крупченко А.К. К вопросу профессиональной лингводидактике// Современная теория и методики обучения иностранным языкам/ - М.: Экзамен, 2004. - с.243.

6. Куклина С.С. Учебная деятельность по овладению иноязычным общением и ее организационные формы // Монография, изд. ВГГУ г.Киров, 2013, - 175с.

7. Локтюшина Е.А. Об изменении требований к профессиональной готовности преподавателей иностранного языка // Научное обеспечение системы повышения квалификации кадров, №2 (15), 2013, с. 12-17.

8. Минакова П.С., Роговая Н.А., Шегай Л.А. Развитие навыков профессиональной иноязычной коммуникации у студентов технических направлений // Современные технологии и методики эффективного обучения иностранным языкам, сборкик материалов он-лайн форума, 2021, с.47-52.

9. Dudley - Evans T. Development in ESP: A Multi-disciplinary Approach $\backslash$ T. Dudley- Evans, M.St.John.- Cambridge: Cambridge University Press, 1998

10. Hutchinson T. English for Specific Purposes: A Learning-centered Approach $\backslash$ T. Hutchinson, A. waters. Cambridge: Cambridge University Press. 1987.

\title{
Рябченко Н.Н. \\ Формирование лингвоэкологической компетентности учащихся в процессе обучения русскому языку
}

ГБОУ ВО «Ставропольский государственный педагогический институт»

(Россия, Ставрополь)

doi: 10.18411/trnio-11-2021-178

\section{Аннотация}

В статье рассматривается специфика формирования лингвоэкологической компетентности обучающихся в практике школьного обучения русскому языку. Автор раскрывает условия формирования лингвоэкологической компетентности у обучающихся, дает описание методов работы, содействующих повышению речевой культуры учащихся, рассматривает систему упражнений, ориентированных на овладение учениками нормами русского литературного языка и обогащение словарного запаса. Статья предназначается для педагогических работников, желающих познакомиться с особенностями формирования лингвоэкологической компетентности обучающихся на уроках русского языка.

Ключевые слова: лингвоэкологическая компетентность, русский язык, языковые нормы русского литературного языка, словарный запас.

\section{Abstract}

The article examines the specificity of the formation of linguo-ecological competence of students in the practice of school teaching of the Russian language. The author reveals the conditions for the formation of linguo-ecological competence in students, gives a description of the methods of work that contribute to improving the speech culture of students, considers a system of exercises aimed at mastering the norms of the Russian literary language by students and enriching the vocabulary. The article is intended for teachers who want to get acquainted with the peculiarities of the formation of linguo-ecological competence of students in the lessons of the Russian language.

Keywords: linguo-ecological competence, Russian language, linguistic norms of the Russian literary language, vocabulary.

В условиях современной школы перед учителем стоит глобальная задача подготовить культурного, высокообразованного человека, творческую личность. Решение обозначенной задачи ориентировано на создание благоприятной языковой и речевой среды, влияющей на духовное развитие ученика, речевую культуру, формирующую его лингвоэкологическую компетентность. Формирование лингвоэкологической компетентности учащихся - это воздействие на языковое и речевое развитие ученика, обучение его правильному речевому поведению. 
В настоящее время проблема формирования лингвоэкологической компетентности обучающихся современных школ представляет собой наибольшую актуальность. В обществе наблюдается преобладание вульгаризмов, жаргонизмов не только в разговорной речи, но и в текстах, создаваемых радио- и тележурналистами, в газетных и журнальных публикациях. Кроме того, современная экономическая и политическая обстановка в стране содействует тому, что процесс проникновения иноязычной лексики в русский язык отличается непредсказуемым характером. Такое обращение с языком незамедлительно отразилось на речи обучающихся школ. Речь учеников характеризуется отсутствием лексического богатства, разнообразия синтаксических конструкций, скудна и невыразительна. Порой школьники для выражения всего спектра чувств, переживаний, впечатлений употребляют большое количество жаргонизмов. Это не может не отразиться на сознании и культуре каждого учащегося, зачастую воплощается в элементарном невежестве, касающемся как истории нашей родины, так и современности [4].

В таких условиях очень важно учителю обучать ученика, воздействуя на духовное развитие, способствуя формированию речевой культуры.

Одним из путей решения проблем формирования лингвоэкологической компетентности в современной школе является реализация следующих условий:

- овладение учениками нормами русского литературного языка в рамках спецкурса «Культура речи сквозь призму экологии языка»;

- обогащение словарного запаса путем вовлечения учащихся в активные диалоговые формы общения.

Рассмотрим их содержание.

Овладение учениками нормами русского литературного языка в рамках спецкурса «Культура речи сквозь призму экологии языка» - одно из ведущих условий в овладении лингвоэкологической компетентностью.

С языковыми нормами русского литературного языка школьники знакомятся при изучении основного курса русского языка. При этом в программе обозначены лишь те нормативные правила, которые нарушаются носителями родного языка, выступают как коммуникативно-значимые, поскольку охватывают большую по объему группу языковых средств или частотные в речи слова, словоформы и конструкции. Полный набор норм русского литературного языка в рамках основного курса русского языка не представлен. Вследствие этого необходима специальная ознакомительная работа, предусматривающая изучение полного состава норм русского литературного языка в рамках спецкурса «Культура речи сквозь призму экологии языка».

Одной из важнейших цеелей спецкурса «Культура речи сквозь призму экологии языка» является формирование языковой и лингвоэкологической компетентности обучающихся.

В числе задач стоят:

— изучить нормы современного русского литературного языка, повысить речевую культуру учащихся;

- создавать условия для сохранения чистоты русского языка как явления культуры;

- содействовать пониманию роли родного языка в развитии интеллектуальных и творческих способностей;

- формировать способность к анализу и оценке языковых явлений.

Содержание занятий в рамках спецкурса предусматривает анализ и классификацию орфоэпических, грамматических, речевых и стилистических ошибок обучающихся, объяснение причин их появления, поиск возможностей их предотвращения; анализ текстов школьных сочинений, текстов мастеров слова; выявление источников словарного обогащения; конструирование, редактирование текста; стилизацию; подготовку публичных выступлений. 
Среди методов, содействующих овладению учениками нормами русского литературного языка, следует выделить: рецептивный метод (показ речевого образца; формирования знаний о речи и речеведческих понятиях, о способах речевой деятельности; заучивание наизусть текстов, которые обеспечивает насыщение творческой памяти учащихся образцами правильной речи); репродуктивный метод (решение типовых речевых задач; анализ слова или текста по данному ранее образцу; составление словосочетаний, предложений; изложение и пересказ текста); метод моделирования (отбор языковых средств для выражения одного и того же смысла различными грамматическими средствами) и др.

С целью повышения эффективности работы в овладении нормами русского литературного языка в рамках спецкурса «Культура речи сквозь призму экологии языка» учителю целесообразно придерживаться следующих рекомендаций.

1. Развивать мотивацию в процессе изучения норм русского литературного языка.

2. Создать условия для осознания учениками понятия «норма» как принятого в языке правила произношения, словоупотребления и осмысление определенной конкретной нормы.

3. Необходимо на уроках организовать многократное повторение правильного варианта произношения слова, словоформ, словоупотребления и т. д. с целью выработки нужного автоматизма произношения, управления одного слова другим и т.д.

4. Использовать целенаправленную систему речевых упражнений, обеспечивающую формирование вначале осмысленных умений, а в последующем - речевых навыков [1].

К числу обозначенных упражнений можно отнести: сопоставительный анализ нормы и ее нарушений; выбор одного из данных (ошибочного и нормативного) языковых средств; замена ошибочных вариантов нормативными (исправление ошибок в произношении слов, в словоупотреблении, в построении предложений и т.д.); устный пересказ или письменное изложение текста, в котором необходимые для усвоения языковые средства выступают опорными; составление словосочетаний, предложений, небольшого текста с языковыми средствами, норму употребления в которых следует не только осмыслить, но и запомнить.

Обогащение словарного запаса путем вовлечения учащихся в активные диалоговые формь общении - это следующее условие в формировании лингвоэкологической компетентности обучающихся.

Коммуникативный смысл этой работы не только в том, чтобы сделать речь учащихся более точной, но воспитать у школьников потребность выбирать наиболее уместные для каждого конкретного случая языковые средства, особенно изобразительные, устранить в их речи нелитературные слова.

Формирование коммуникативных качеств хорошей речи у учеников - особая сторона работы по культуре речи. Обогащение речи учащихся предполагает осознание ими оттенков лексических и грамматических значений слов, словоформ, конструкций, а также их стилистических особенностей, сферы употребления. Это осмысление выступает той основой, на которой строится обучение выбору (из имеющегося в речевой памяти) оптимального для определенной речевой ситуации языкового средства [2].

Реализуя задачи обогащения речи школьников, словесник формирует у них оценочное отношение к отбору языковых средств в зависимости от комплекса таких факторов, как задача, адресат, время, место высказывания и т.д.

Следует отметить, что обогащение словарного запаса обучающихся может осуществляться весьма эффективно в процессе активных диалоговых форм на уроках русского языка. Наиболее приоритетными в этом отношении выступают продуктивные методы (многочисленные речевые задачи проблемного характера); интерактивныле методы (ролевые игры и дискуссии); метод моделирования (моделирование речевых ситуаций, которые имитируют процесс порождения речи с определенной целью). 
Суть использования продуктивных методов предусматривает выполнение упражнений в строго заданной форме. Так, обогащение словарного запаса посредством вовлечения учащихся в активные диалоговые формы можно осуществлять на уроках русского языка с помощью специальных речевых упражнений, предусматривающих взаимодействие учеников друг с другом. Наиболее эффективными в этом отношении выступают.

1. 1.Условно-коммуникативные

упражнения

(имитативные, трансформационные, репликовые с целью варьирования лексического наполнения, отработки речевых клише).

2. Драматизация диалога с возможностью внесения различных модификаций.

В этом случае заслуживают быть отмеченными ролевые игры в форме беседыинтервью, в которых один из участников играет роль человека, берущего интервью с целью получить информацию у одного или нескольких учащихся - интервьюируемых. Интервьюеры составляют 4 вопроса по теме, продумывают вместе с интервьюируемым ответы.

Наряду с этим необходимо отметить важную роль в обогащении словаря также приема моделирования ситуащий, который требует учета обеих форм контакта монологической и диалогической. В качестве единиц, характеризующих речевой продукт в рамках моделирования ситуаций при обучении продуктивной деятельности выступают не только фраза и связный текст монологического характера, но и развернутый диалог.

Ведущее место в этом случае принадлежит воображаемым ситуациям. Модели воображаемых речевых ситуаций предполагают выход за рамки урока русского языка или за пределы личного опыта своей возрастной и социальной группы. Участие в них требует перенесения в предполагаемые обстоятельства и служит средством обучения [3].

Таким образом, использование моделирования ситуаций как приёма вовлечения учащихся в активные диалоговые формы общения требует включения ролей, которые являются хотя и нетипичными для ученика, но выступают для него как перспективные. Моделируя ситуации общения необходимо учитывать, что результат может вылиться в продуцирование самых разнообразных по функциям, структуре и степени развернутости текстов диалогического характера.

Из сказанного становится очевидным то, что обозначенные формы работы с учащимися ориентированы на активизацию и уточнение словаря у учеников, содействуют усвоению отдельных диалогических единств, построенных из различной компоновки лексико-грамматических средств, закрепляют речевые навыки, например, при построении учебного диалога, путём постановки проблемных вопросов, на этапе рефлексивной деятельности, формируют умения отбирать языковые средства в зависимости от ситуации общения.

В итоге рассмотрения вопроса целесообразно отметить, что создание условий формирования лингвоэкологической компетентности у обучающихся представляется важным с позиции безопасной лингвистической социальной среды, ее оздоровления в условиях современной школы.

$$
* * *
$$

1. Архипова Е.В. Основы методики развития речи учащихся: учебник и практикум для вузов. М.: Издательство Юрайт, 2017. 202 с.

2. Баранов М.Т., Пентилюк М.И. Методика преподавания русского языка в школе. М.: 2000. 250 с.

3. Панфилова А.П. Инновационные педагогические технологии. Активное обучение: монография. М.: Академия, 2012. $192 \mathrm{c.}$

4. Сущенко Е.А. Педагогическая лингвоэкология как фактор безопасности жизнедеятельности субъектов образовательного процесса: автореферат дис. ... доктора педагогических наук: 13.00.00; [Место защиты: Междунар. акад. наук экологии и безопасности жизнедеятельности]. Санкт-Петербург, 2013. 61 с. 